\title{
Heraclitus, DK 22 B 44 (frg. 103, Marcovich)
}

\author{
Tomáš Vítek \\ The Institute of Philosophy, Prague \\ tomas.vitek7@gmail.com \\ Heráclito, DK 22 B 44 (frg. 103, Marcovich)
}

\begin{abstract}
The authenticity of Heraclitus ' fragment B 44 can be doubted on account of the following reasons: 1. stylistic and syntactic anomalies (problematical articles, a strange looking insertion of $\dot{v} \pi \dot{\varepsilon} \rho$

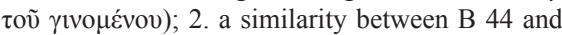
B 115 (duplication of the same metaphor); 3. an incongruity between the message of B 44 and Heraclitus' views; 4. anachronistic meaning of the term vó $\mu$ o $\varsigma$ which could not refer to a law in Heraclitus' lifetime; 5 . an analogy with trivial gnomic wisdom; 6. an analogy with Heraclitean falsa in a moralistic spirit; 7. a connection of B 44 with B 43 that are not found anywhere else. These objections do not exclude the authenticity of the fragment, but its defenders should neutralize them with some strong arguments.
\end{abstract}

Key words: Heraclitus; Greek philosophy; vónos; $\delta \tilde{\mu}$ o ; fight; gnomic wisdom.
La autenticidad del fragmento B 44 de Heráclito puede ser cuestionada por los siguientes motivos: 1. anomalías estilísticas y sintácticas (artículos

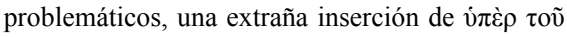

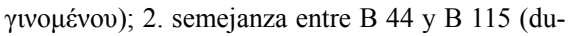
plicación de la misma metáfora); 3. incongruencia entre el mensaje of B 44 y las posiciones de Heráclito; 4. significado anacrónico del término vó $\mu$ os que no podía hacer referencia a una ley en tiempos de Heráclito; 5. analogía con la sabiduría gnómica tópica; 6. analogía con los falsa heracliteos de tenor moralizante; 7. existencia de una conexión de B 44 con B 43 que no se encuentra en ningún otro lugar. Semejantes objeciones no excluyen la autenticidad del fragmento, pero sus defensores debieran contrarrestarlos con argumentaciones sólidas.

Palabras clave: Heráclito; filosofía griega; vó $\mu$ os; $\delta \tilde{\mu}$ о; lucha; sabiduría gnómica.

Almost all scholars accept the text referred to in Diels's edition of Heraclitus' fragments as B 44 as authentic. And yet, though the number of experts who reject its authenticity is extremely small ${ }^{1}$, various pieces of evidence put this text under a cloud of suspicion. This article's author will try to highlight and further support the position of the sceptics. The aim, however, is not to relegate this fragment among the falsa but rather to provide the advocates of its authenticity with an opportunity to refute the introduced objections. Many scholars

${ }^{1}$ Schwarz 1905, p. 748; Deichgräber 1939, pp. 12-13; Rosén 1988, pp. 36-37; Vítek 2003, p. 368 . 
seem to support the authenticity of B 44 by default rather than on basis of a thorough analysis of arguments for and against it. Another, in a way subsidiary aim of this article is to point to certain inconsistencies in the treatment of fragments that are generally accepted as true or false.

These are the objections can be raised against the authenticity of B 44:

\title{
1. Stylistic and syntactic anomalies
}

In most manuscripts, the text appears in the following form:

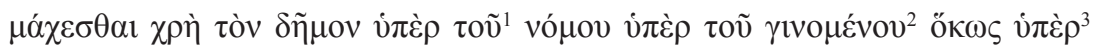
$\tau \varepsilon i ́ \chi \varepsilon \circ \varsigma$.

The people must fight for the law — for that which now exists (?) — as for their city-wall.

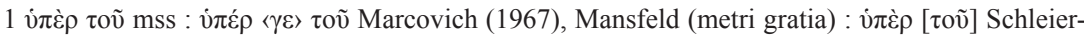

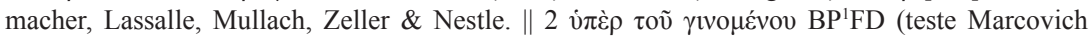

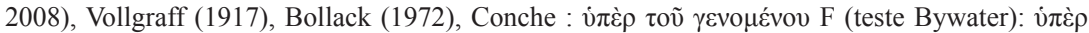

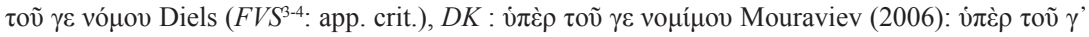

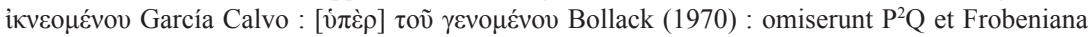
(1533) : secluserunt ut dittographiam Schleiermacher, Lassalle, Mullach, Zeller \& Nestle, Snell, Patrick (1989, p. 130), Diels (1901, FV ${ }^{1-2}$ ), Burnet, Walzer, Jones, Kahn, Marcovich (1967), Robinson, Mansfeld, Diano \& Serra, Colli, Mondolfo \& Tarán \& Marcovich et alii. || 3 ö $\omega \varsigma$ vं $\pi \dot{\varepsilon} \rho$ BPFD, Schleiermacher, Lassalle, Mullach, Zeller \& Nestle, Bywater, Patrick (1989, p. 130), Vollgraff (1917), Long, Bollack \& Wissman, Kahn, Conche et alii: ö $\omega \sigma \pi \varepsilon \rho \mathrm{W}$, Meineke (teste Diels 1901), Diels, Snell, Kirk \& Raven, Marcovich, Robinson, Mansfeld, Colli, García Calvo, Marcovich \& Mondolfo \& Tarán, Mouraviev (2006) et alii.
\end{abstract}

The first conspicuous feature that may catch our eyes are the articles fronting $\delta \tilde{\eta} \mu$ ov and vó $\mu$ ov standing in contrast with $\tau \varepsilon i ́ \chi \varepsilon o \zeta$, where the article is omitted. In anyone else's writing, such irregularity would not be problematic but Heraclitus treated articles with parsimony and plenty of consideration. Only about one third of extant fragments (i.e., approximately 60 of them) contain an article, and in most cases it plays some important grammatical or semantic function (such as expressing opposition, fronting participles, endowing words with a different meaning, or emphasising the meaning of a word $)^{2}$. Most scholars accept that articles in this fragment fall into this category ${ }^{3}$. Those who

${ }^{2}$ For more on this point, see Vítek 2003, pp. 366-368.

${ }^{3}$ Cf. Bollack 1972, p. 161, and especially Mouraviev 2006 (III.3.B/ii), p. 70 (the article fronting $\delta \tilde{\eta} \mu$ o $\varsigma$ should be understood in the sense of «ce peuple», i.e., the people of Ephesus, while the article in front of vó $\mu$ ov is individualising in the sense of «la loi de la cité»). 
are not content to believe that Heraclitus ascribed the same value to «law» and «people» (see point 3) may chose to explain the presence of articles as a consequence of: $a$ ) indirect speech used in retelling the statement; $b$ ) stylistic and metric modifications; $c$ ) later changes by other authors some of whom include the article while others do not (cf. B 51, B 76, B 99, B 125 and others); d) inauthenticity of the fragment or some of its parts (cf. for example B 126a).

In the case of B 44, the first option may be worth further consideration because of the introductory $\varepsilon \dot{\varepsilon}\langle\gamma \varepsilon$ (see point 7). Advocates of authenticity reject this option, usually with reference to the presence of $\chi \rho \eta$. The second option does not seem too plausible because stylistic reasons seem to be absent and it is still doubtful whether the statement has a metric form at all: Diels and Marcovich claim to recognise a iambic trimeter in the text but only after making changes to its wording, and even so they cannot support the assumed measurement with convincing reasons ${ }^{4}$. The third option cannot be assessed due to lack of other sources but even so it has its proponents ${ }^{5}$. The fourth option also remains open since Diogenes Laertius, who only quotes the B 44, belongs to authors «convicted» of inserting inauthentic additions into Heraclitus' texts. It

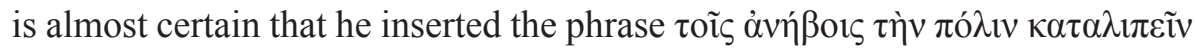
into B 121 since no other author includes it as a part of this fragment. Similar-

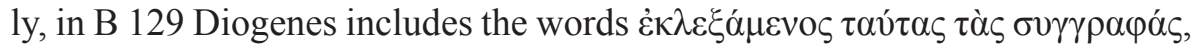
which some scholars believe to be an inauthentic addition and a reason to doubt the entire fragment ${ }^{6}$.

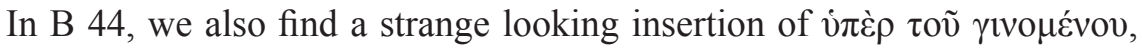
nowadays usually removed from the text even by most scholars who are convinced of the fragment's authenticity (see app. crit.). What is problematic here is not the article itself but rather the meaning of the insertion within the statement as a whole. Though this predicament may be to some degree disguised by a suitably interpretative translation ${ }^{7}$, one may well ask: $a$ ) why should people

${ }^{4}$ Bollack 1970, p. 8, n. 3, is critical on this point. Cf. Diels 1912 (=FVS3), p. 96 (app. crit.

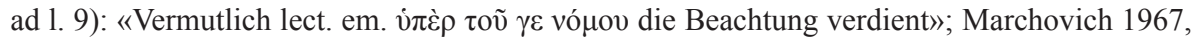
p. 534.

${ }^{5}$ Article in front of vó $\mu$ ov is omitted by Schleiermacher 1838, p. 26, and Mullach 1860, p. 317.

${ }^{6}$ Schleiermacher 1838, p. 21; Lassalle 1858, p. 309, n. 1; Gomperz 1886, p. 1003; Zeller 1889, p. 988; Diels 1901, p. 29; Corssen 1912, pp. 254-255; Kranz 1934, pp. 115-116; Colli 1980, p. 128; Vítek 2003, p. 368.

${ }^{7}$ Bollack 1972, p. 161: «Loi, pour celle qui se fait»; Bollack 1970, p. 4: «les citoyens se cramponnent aux lois existantes»; Conche 1986, pp. 220: «loi — pour celle qui existe», 222: 
fight (only) for a law that «emerges or is», and not for one that is already in existence? $b$ ) why should an emerging law, one that is certainly not yet very solid and «written in stone», be likened to a city wall, a symbol of firmness and stability? c) why would an author known to be extremely pithy in his expression include an insertion that neither clarifies, specifies, or adds depth to the message of his statement? These doubts cannot be fully removed by various conjectures since those either reduplicate what was already said (Mouraviev) or say the same thing in a slightly different way (Bollack, García Calvo).

\section{Duplication of the main metaphor}

A strong analogy with B 44 is found in the first part of B 114, where it is demanded that «those who speak with reason must lean on what is common

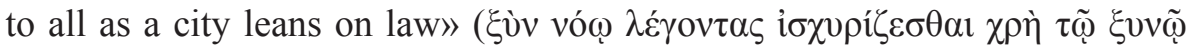

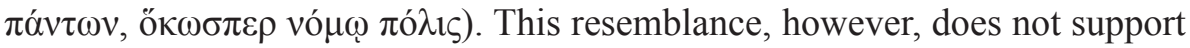
the authenticity of B 44 since comparison with B 114 reveals just how much the metaphor was flattened and simplified. In one text, the ability to speak with reason is described as founded on a cosmic $\lambda$ ó $\gamma o s$, which is shared by all just like the laws of a community - this, among other things, lends to the $\lambda$ ó ${ }^{\circ} \varsigma$ a dimension of a law and to the laws of a community a dimension of $\lambda$ óros while in the other text, we find but a rather trite appeal to fight for the observance of laws, hardly implying some potential deeper meanings or connections.

Duplication of a metaphor is not rare in the corpus of Heraclitus' sayings, and for the most part, it is tacitly accepted as one of the peculiarities of his style. Even so, it is noteworthy that many of the fragments that are often suspected of inauthenticity share this particular feature. For example B 4, where happiness based on bodily pleasures is compared to the joy of oxen finding a vetch, looks like a flatter and skewed variation of B 9 («Asses prefer straw to gold») and of B 13 («Pigs delight in the mire more than in clean water») ${ }^{8}$.

«la loi qui est sa loi» and 222: «la loi telle qu'elle existe». Vollgraff 1917, pp. 168-180, even

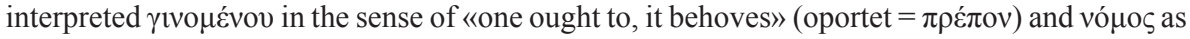
the sum of human and divine law («populum ius ac fas instar muri tueri oportet»); García Calvo 1985, pp. 269-270, in his explication «la ley, por la bien ordenada al menos» takes a similar line. Diano \& Serra 1980, p. 185, and Mouraviev 2006 (III.3Biii), p. 53, point out that the text in its unmodified form is almost untenable and very difficult to translate.

${ }^{8}$ B 4 is rejected or left out by Schleiermacher, Lassalle, Mullach, Schuster, Bywater, Wheelwright, Marcovich 1967, p. 189, Bollack \& Wismann (pointing out it is a paraphrase of 
Albertus clearly violated the logic of the original saying, which demonstrated the relativity of values using an example of a choice between gold and straw, in order to somewhat obviously emphasise the similarity between a person seeking bodily pleasures and an ox coveting a vetch ${ }^{9}$. Another metaphoric doublet, B 37 («Swine wash in the mire, and barnyard fowls in dust»), too, looks like an inferior periphrase of B $13^{10}$. Similarly, fragment B 136 («Souls slain in battles by Ares are purer than souls slain by illness»), which is usually rejected as inauthentic, seems to be a later rendition or a simplifying explanation of the provocative statement of B 24, according to which «gods and men honour those who are slain by Ares». Likewise, the claim that «the wisest of men, in contrast to God, appears as an ape in wisdom and beauty and all things» (B 83) bears a striking resemblance to $\mathrm{B} 82$, according to which «the most handsome of apes is ugly in comparison with a human». In this case, too, syntactic ambiguity and terseness of expression favour B 82 as a model but it possible that both B 82 and B 83 imitate another, similar statement ${ }^{11}$.

Not all reused metaphors display such conspicuous simplification of or deviation from elaborate polysemy of a hypothetical original. Statements «we step and do not step into the same rivers» (B 49a) and «it is not possible to step twice into the same river» (B 91) were in all probability based on B 12 where it is said that «on those who enter the same rivers, ever different waters flow» ${ }^{12}$. B 12 emphasises the concurrent identity and lack of

B 9 and especially of B 13), Kirk, Colli and Pradeau; Kahn and Robinson treat it with serious reservations.

${ }^{9}$ Cf. second part of B 29 where ordinary people are «glutted like beasts». (This fragment is seen as a possible inspiration or support by Gigon 1935, p. 121, Fränkel 1938, p. 322, and Guthrie 1962, p. 478.) Bywater 1880, pp. 231-232, Kirk 1978, pp. 85-86, and Marcovich 1967, p. 189 , point to a faulty logic of reproduction and statement's quasi-theological slant but not all of them see it as a sufficient reason for rejecting the fragment's authenticity altogether (Bywater).

${ }^{10}$ Older scholars usually did not include the statement transmitted by Columella in their editions (Schleiermacher, Mullach, Schuster, Lassalle); among the more recent editors, it is explicitly rejected, e.g., by Kirk 1978, pp. 76-77, 79-80, Bollack \& Wismann 1972, pp. 70, 147 , Kahn 1981, p. 288, and Robinson 1987, p. 105 (with hesitation).

${ }^{11}$ Scholars often reject the authenticity of the wording of both fragments (see already Bernays 1848, pp. 23-24) but usually presuppose a common source (mainly B 79, cf. Fränkel 1938, pp. 315-316; Marcovich 1967, pp. 488-489; Bollack \& Wismann 1972, pp. 248-249; Kahn 1981, p. 174; Robinson 1987, p. 133). Others even tried to reconstruct such a source from the two statements (Mouraviev 2006, III 3.B/i, p. 212).

12 Mullach 1860, I 317; Gigon 1935, pp. 106-107; Kirk 1978, pp. 373-376, Marcovich 1967, p. 211; Kahn 1981, pp. 288, 339, n. 431; Dilcher 2005, pp. 203-204; partly also Guthrie 
identity of a river and its waters, while B 49a and B 91 focus on the observer who steps into a river and cannot achieve identity. Yet it would be hard to turn this into a convincing case against the authenticity of these statements since they may be seen as presenting different views of the problem ${ }^{13}$. Somewhat unclear is also the situation of the maxim that «thought is common to all» (B 113). While at first glance it resembles a simplified excerpt from B 2

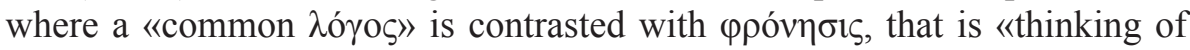
[one's] own» (or, depending on translation, «private intelligence») $)^{14}$, it also opens new avenues of interpretation, e.g., the question whether really everyone, including animals, plants, and things take some part in thinking ${ }^{15}$.

Accordingly, the existence of such semantic and metaphorical doublets could be explained in various ways. Sometimes, (1) they may have been created unwittingly, for example, when an author intended to reproduce the original but did not recall the wording correctly. In other cases, (2) one can assume that some authors intentionally created a new variant which they saw as better suited in a particular context. At other times, creation of a new version of Heraclitus' saying may have resulted from doxographers's aim to think in Heraclitean spirit or to develop his claims further (this suspicion is relevant especially to the Stoics). And finally, (3) it is possible that Heraclitus himself repeated and amended his own thoughts and images. In the case of some fragments, this may well be defensible but if one of the two similar versions is notably dull and inferior, it may be advisable to place such a statement in the previous two groups rather than take recourse to constructing elaborate apologies and suppose that Heraclitus was not always in top shape.

\section{Incongruity between the statement and Heraclitus'views}

Rather suspicious feature of B 44 is the positive emphasis on people $(\delta \tilde{\eta} \mu \circ)$ whom Heraclitus usually treated with disgusted loathing, speaking of them

1962, pp. 441, 490-491 (B 91 is a late paraphrase of B 12, and same probably holds of the second part of B 49a, though Heraclitus may have expressed the same thought several times in different ways).

${ }_{13}$ Cf. e.g. Reinhardt 1916, pp. 61-62, or Snell 1926, pp. 355-356. For a critical view see Dilcher 2005, pp. 203-205.

${ }^{14}$ Kirk 1978, pp. 55-56, Marcovich 1967, pp. 96-97, and Dilcher 1995, p. 57, reject authenticity for these reasons.

${ }^{15}$ Cf. Reinhardt 1916, p. 214; Gigon 1935, pp. 16-17; Guthrie 1962, p. 426, n. 1; Bollack \& Wismann 1972, pp. 314-315; Mouraviev 2006 (III 3.B/iii), p. 135. 
as «the many, the masses» (oi $\pi$ o $\lambda \lambda$ oí). This attitude is aptly summed up in a categorical claim that «the many are bad», regardless of whether this was uttered by Bias, whom Heraclitus mentions, or Heraclitus himself ${ }^{16}$. Ordinary

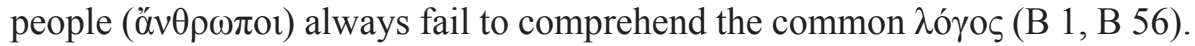

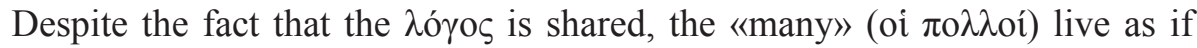
they had a wisdom of their own (B 2). The «many» ( $\pi \mathrm{o} \lambda \lambda \mathrm{oi}$ ) are unaware of the real form of things and prefer appearances to knowledge (B 17). In numerous fragments, these ignorant fools who in their barbaric souls cannot understand, differentiate, apprehend, hear, or speak, are referred to simply by a plural (B 17, B 19, B 20, B 34, B 51, B 107, B 121). In other statements, «the many» represent the negative opposite of an individual or of refined people:

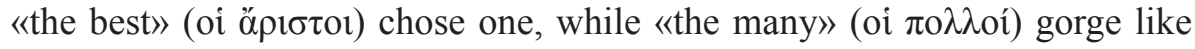
cattle (B 29); fools trust folk singers and their teacher is the crowd ( $\delta 1 \delta \alpha \sigma \kappa \alpha ́ \lambda \omega$ $\chi \rho \varepsilon i ́ \omega v \tau \alpha l$ ó $\mu$ í $\omega$ ) because they cannot not tell apart good and evil (B 104),

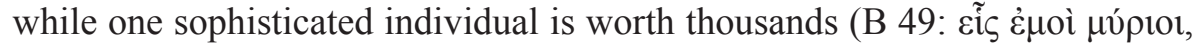

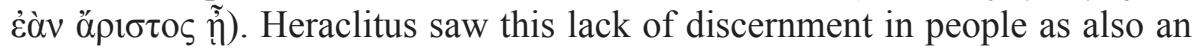
ontological shortcoming since «the many» cannot even tell apart what is wise

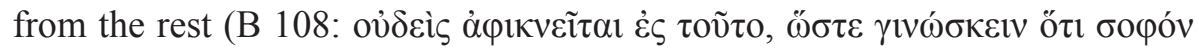

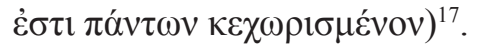

In this context, exhorting people to fight for their laws like they would fight for city walls seems rather odd. It follows from the above-mentioned quotations and paraphrases that in Heraclitus' view, the «many» are incapable of establishing good laws since they cannot see things as they are, cannot distinguish good from bad or important from insignificant, and they do not look for law where it really is (i.e., in the divine $\lambda$ ó $\gamma \circ \varsigma$ ). The philosopher had no reason to exhort Ephesians or any other people to fight for the preservation of or compliance with laws: he radically doubted the ability of ordinary people to recognise when, how, and against whom such laws should be defended ${ }^{18}$.

Miroslav Marcovich thought that B 44 may be a kind of a political slogan in a metric form which Heraclitus composed for Ephesians in times of political crisis, indicating that as city walls protect from an external enemy, laws represent a protection against an internal enemy, especially against those

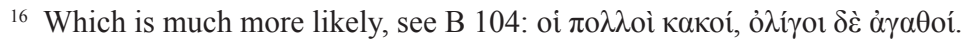

${ }_{17}$ Cf. Kindstrand 1984, pp. 167-170.

${ }_{18}$ Highly positive attitude of Heraclitus to the people ( $\delta \tilde{\eta} \mu \circ \varsigma$, not $\left.\lambda \alpha^{\alpha} \circ \varsigma\right)$ is proposed perhaps only by Lledó 1994, pp. 257-268, but unfortunately, the B 44 is the sole evidence for his projective and emphatically pro-democratic interpretation (which is a classical circulus uitiosus). 
who may aspire to tyrannical rule ${ }^{19}$. This hypothesis was certainly well meant, and it may facilitate the defence of other, similarly simple appeals from the Heraclitean corpus but Heraclitus' style of thought and all available evidence contradicts $i^{20}$.

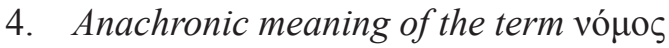

Before the second half of the $5^{\text {th }}$ century, the term vó but rather «custom». In literature, the first use of the term in the sense of «law» is attested only in $442 \mathrm{BCE}$ in the writing of Sophocles who applied it to the edicts of the Mycenaean ruler Creon ${ }^{21}$. Novelty of this meaning is further confirmed by the fact that writers living at this time or shortly after often added to

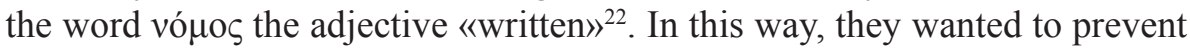
possible confusion with traditional customs because the new laws crucially differed from old customs by being fixed in writing ${ }^{23}$. In the older stratum of legislative texts, the term vó $\mu$ o meaning can be attested only around mid $-5^{\text {th }}$ century ${ }^{25}$. This new meaning quickly caught on and spread, and in the course of the Hellenistic period be-

${ }_{19}$ Marcovich 1967, pp. 534-535. Similar position is adopted also by Kindstrand 1984, p. 170, and Conche 1986, pp. 6, 223.

${ }^{20}$ Bollack 1970, p. 4.

${ }^{21}$ Antig. 449, 452, 481, 663, 847.

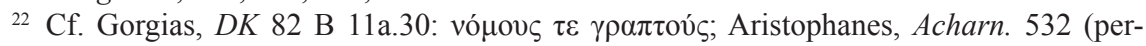

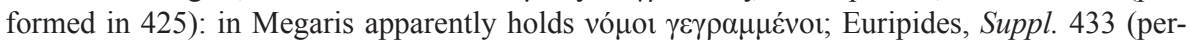
formed after 424): $\gamma \varepsilon \gamma \rho \alpha \mu \mu \varepsilon ́ v \omega v \delta \varepsilon \grave{\varepsilon} \tau \tilde{\omega} v$ vó $\mu \omega v$.

${ }^{23}$ This is further confirmed by numerous new terms used to denote laws: «that, which was

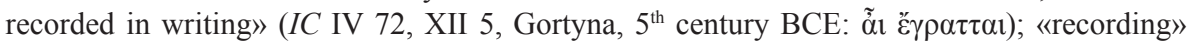
(IOlymp 7.2 and 9.7-8, Olympia, both from $6^{\text {th }}$ BCE: $\gamma \rho \alpha ́(\rho) \varsigma$ ), «inscription» (SEG XXX 380, Tiryns, $7^{\text {th }}$ century BCE: $\gamma \rho \alpha \dot{\theta} \mu \alpha ; I G$ IV, 506.1, Argos, $6^{\text {th }}-5^{\text {th }}$ century BCE: $\left.\gamma \rho \alpha ́ \mu \mu \alpha\right)$ etc. For more references see Hölkeskamp 1999, p. 277, or Gagarin 2005, p. 37.

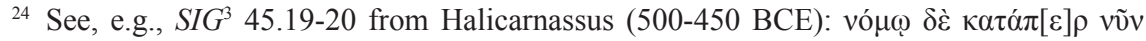

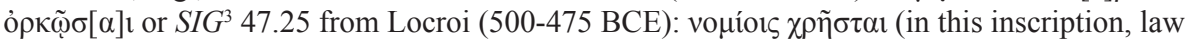
is on line 46 referred to by the term $\theta \dot{\varepsilon} \theta \mu 10 v)$.

${ }^{25}$ Sometimes, edict IE 33 from Erythrai issued around 450 BCE is seen as the first ex-

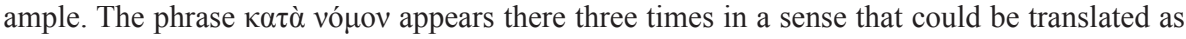
"according to the law». With full certainty, however, the new meaning is attested only at the end of the $5^{\text {th }}$ century: see e.g. a revision of Draco's law on murder of 409/8 BCE (IG $\mathrm{I}^{2} 104.4$

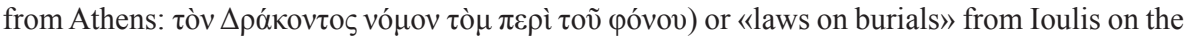
island of Keos from late $5^{\text {th }}$ century BCE (IG XII 5, 593: oí $\delta \varepsilon$ vó $\mu$ or $\pi \varepsilon \rho \grave{~} \tau \tilde{\omega} \gamma \kappa \alpha \tau \alpha \varphi \theta \mu \varepsilon \dot{\varepsilon} v \omega v$ ). Ostwald 1969, pp. 50-51; Thomas 2005, p. 51. 
came the main expression for «law» in the entire Greek territory, though even at that time some regional terms persisted (e.g., in Sicily).

It follows then that at the end of the Archaic period, in Heraclitus' lifeti$\mathrm{me}^{26}$, vó $\mu$ o $\varsigma$ could not refer to a law ${ }^{27}$. Nonetheless, a struggle for vó $\mu$ or was in fact going on at that time, not only in Ephesus but all over Greece. Laws became the means of a struggle whereby various communities since approximately mid- $7^{\text {th }}$ century sought to limit the power of important aristocratic families and introduce a measure of order and predictability into the decision-making process in courts and assemblies. Written, therefore verifiable and publicly accessible laws were seen as a protection against arbitrary application and interpretation of the old and often ambiguous customary law, whose implementation used to be firmly in the hands of the most important aristocrats ${ }^{28}$.

Should we then read the statement as referring to vó $\mu$ or within the contemporary meaning spectrum? That would seem ill-advised though some scholars suggest that in this context, vó $\mu$ os could be translated as «political establishment», «legal order» or even «normative conduct» ${ }^{29}$. True, according to legends Heraclitus was the scion of an old aristocratic family, which in consequence of this struggle and with the rise of democrats lost real power ${ }^{30}$.

${ }^{26}$ Heraclitus is usually thought to have lived in about 540-480 BCE since he was supposedly at the height of his powers around the year 500 and lived to be about 60 years old (cf. Freeman 1946, p. 104; Kirk \& Raven 1957, pp. 182-183; Guthrie 1962, p. 408; Marcovich 1967, pp. 252-255; Kirk 1978, pp. 2-3; Conche 1986, pp. 5-6). Various sources, however, provide often unreliable and sometimes mutually contradictory information (Kirk \& Raven 1957, pp. 182-183; Guthrie 1962, p. 408; Mouraviev 2003, p. 122). Some scholars therefore place the philosopher's life into the entire first half of the $5^{\text {th }}$ century (Reinhardt 1916, p. 157: his manuscript appeared after 478; Colli 1980, p. 171: 510-450; Mouraviev 2003, p. 110: 520-460) while others prefer much earlier dating, especially because of the assumed influence Heraclitus' philosophy on Parmenides (Burnet 1930, p. 130; Wellmann 1912, pp. 504-505; Freeman 1946, p. 104; Kirk \& Raven 1957, p. 183; Guthrie 1962, p. 408; Kirk 1978, pp. 2-3; Conche 1986, p. 5). Most detailed analysis of chronology of Heraclitus' life is found in Mouraviev 2003, pp. 3-10 (M 2-M 7), 110-129.

27 See, e.g. Quass 1971, pp. 14-18.

28 Jones 1956, p. 102.

${ }^{29}$ Cf. Heinimann 1945, p. 67: «politische Ordnung, die Verfassung der Polis»; Ostwald 1969, pp. 20, 26, 30: «valid and binding order», «way of life or mores of a city as a whole», and «law-and-order»; Quass 1971, pp. 17-18: «normative Verhaltensweise», «Normträger»; cf. also Dilcher 1995, pp. 49-50.

${ }^{30} \mathrm{DK} 22 \mathrm{~A} \mathrm{1}$, par. 6; A 2. Once again, historicity of all of this information is highly doubtful since there are almost no extant sources pertaining to the political situation and demographics of Ephesus at the end of the Archaic period (cf. Vlastos 1947, p. 166; Kirk 1978, pp. 3-5; Kirk \& 
It is therefore theoretically possible that he may have seen the old (unwritten) customs as preferable to the new written laws ${ }^{31}$. But such interpretation is undermined by the demand that it be the people who defend the old customs which were actually not to their advantage. The idea of fighting for the preservation of a particular political regime also does not sound too plausible since Heraclitus in various fragments and testimonies repeatedly condemns it.

The best reading of the statement is obtained by assuming it refers to a «law», and all interprets and extant variations of the same metaphor (see point 5) concur on this point. In supporting this interpretation, scholars usually rely on other Heraclitean fragments in which they interpret vó $\mu$ os in this or a roughly similar sense (B 33, B 114) ${ }^{32}$, and suppose both that the philosopher meant the divine law, as was common in his time ${ }^{33}$, and that the difference between a custom and a law was almost negligible ${ }^{34}$. The problem with this explanation is that the examples they invoke either do not confirm the use of vó $\mu$ os in the sense of «law» ${ }^{35}$ or come from the

Raven 1957, p. 184, n. 1; Guthrie 1962, p. 409; Wellmann 1912, pp. 504-505; Marcovich 1967, p. 535; Kahn 1981, p. 180, n. 222; Kindstrand 1984, p. 170; Hölkeskamp 1999, pp. 109-114; Mouraviev 2003, p. 129-132).

31 Cf. Conche 1986, p. 223; Mondolfo \& Tarán \& Marchovich 2007, pp. 745-746.

32 Cf. Lassalle 1858, pp. 435-436; Fränkel 1938, pp. 320-321. Schleiermacher 1838, p. 28, even considers the possibility that B 44 was part of the text of B 114 .

33 Zeller \& Nestle 1920, pp. 838, 913-914; Kirk \& Raven 1957, p. 214; Wheelwright 1959, pp. 87-88; Marcovich 1967, p. 534; Kahn 1981, pp. 179-180; Mondolfo \& Tarán \& Marchovich 2007, p. 745. Cf. also Vlastos 1947, pp. 166-167, n. 109.

34 See Wheelwright 1959, p. 87.

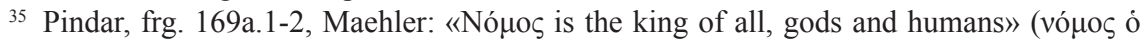

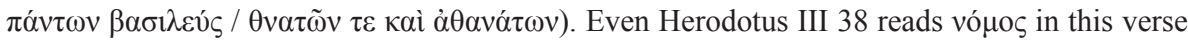
as a «custom» (Latte 1946, p. 73, Ostwald 1969, pp. 37-38, Quass 1971, p. 18, and others agree with him on this point), while all later authors interpret it unequivocally as a «law». Similarly

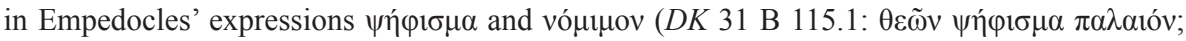

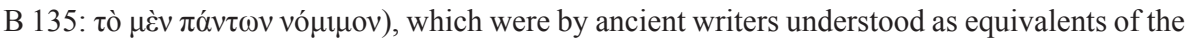

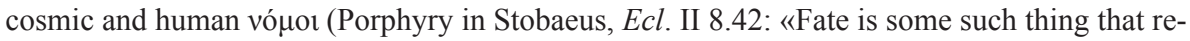

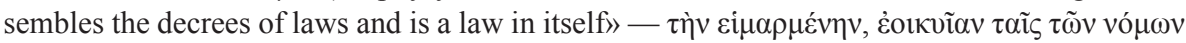

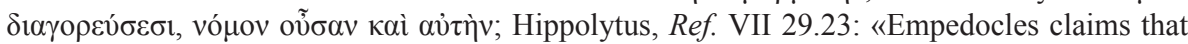

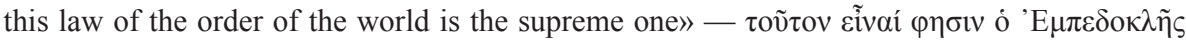

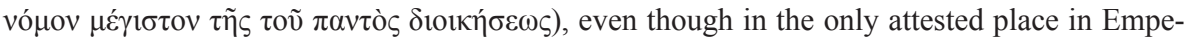
docles vó ${ }_{0} \varsigma$ means quite clearly and unequivocally «custom» (DK 31 B 9.5: «They surely

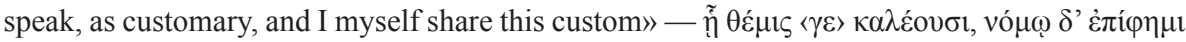

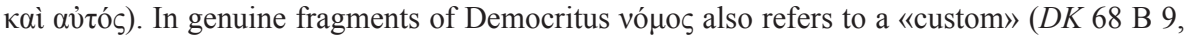
B 125), while in dubiosa and falsa it means «law» (see B 262: in manuscripts there appears 
second half of the $5^{\text {th }}$ century, when vó $\mu$ o $\varsigma$ started being used to mean «law» in various contexts ${ }^{36}$.

After all, B 33 makes good sense even when we read it as «it is also customary to obey the will/advice of one» (vó $\mu$ os $\dot{\varepsilon} \sigma \tau \imath \tau \imath v)^{37}$. Fragment B 114 is very problematic indeed but even here vó $\mu$ o $\varsigma$ can be read in the traditional sense of «custom, practice, habit, order» ${ }^{38}$. Moreover, it is possible that Heraclitus also played with the meanings of a differently accented but otherwise identical word vouós («pasture, fodder, food») as in the case of ßíos and ßió (B 48). The use of the verb $\tau \rho \varepsilon ́ \varphi o v \tau \alpha$, which is otherwise hard to explain, may support this hypothesis ${ }^{39}$. And there are other reasons that speak against

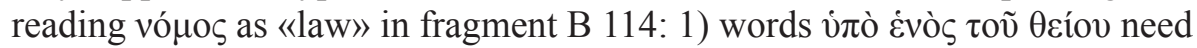

voṽv). Even Aeschylus' $\pi \mathrm{o} \lambda 1 \tilde{\omega}$ vó $\mu \omega$ should not be translated as «by the law of the community» (Suppl. 673: the play was staged in 466-463) though some interpreters tend to do so (see, e.g., Ostwald 1969, p. 28).

36 Thucydides III 82.6 (transl. S. Lattimore): «They strengthened their trust in one another

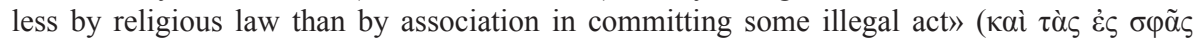

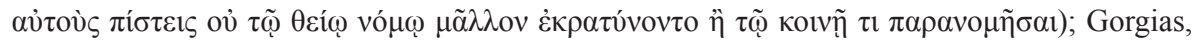
$D K 82 \mathrm{~B} \mathrm{6}$, says of Athenians who died in the war that «many times they preferred the correctness of words to strict law, because they believed this to be the most divine and universal law: to say and not say and do and not do the right thing at the right time» ( $\pi \rho \circ \kappa \rho i ́ v o v \tau \varepsilon \varsigma \pi \circ \lambda \lambda \grave{\alpha}$

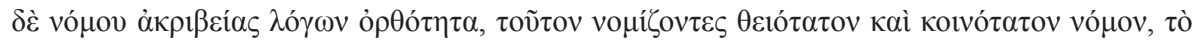

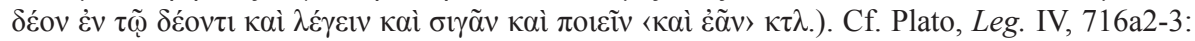
«Justice always accompanies him [i. e. Zeus], and is the punisher of those who fall short of the

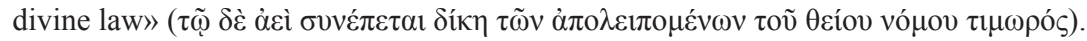

37 This option was considered, for example, by Marcovich 1967, p. 537: «Conformable to custom and tradition»; Robinson 1987, p. 33: «Law or custom»; or Mondolfo \& Tarán \& Marcovich 2007, p. 747: «conforme alle consuetudini e alla tradizione».

${ }^{38}$ See, e.g. Reinhardt 1916, p. 215: «Folglich müssen die $\alpha v \theta \rho \omega ́ \pi \varepsilon 101$ vó $\mu$ oı von den staatlichen Gesetzen und Sitten wesentlich verschieden sein: es sind die Satzungen der ganzen Menschheit, vó $\mathrm{o}_{\mathrm{o}}$ in demselben erkenntnistheoretischen Sinne, den wir bei Parmenides entde-

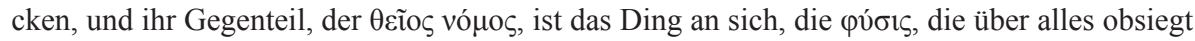
und deren Macht sich selbst bis in die Menschensatzungen hinein erstreckt». Cf. also Reinhardt 1916, pp. 216-217, Gigon 1935, pp. 12-14; Quass 1971, p. 18; Battegazzore 1979, pp. 55-57; or Dilcher 1995, p. 49 («the totality of rules, customs, and forms of behaviour that are valid and followed in one city»). Heinimann 1945, p. 66, Kirk 1978, pp. 51-52, and Ostwald 1969, p. 27 , on the other hand, reject such a distinction even though Heinimann tends to understand vó $\mu$ ○ broadly as «das Geltende» (as in «geltenden Sitten und allgemein anerkannten Maßstäbe des Denkens»), while Ostwald admits that vó $\mu$ or here «must be taken in a wider sense as referring to the way of life or mores of a city as a whole» (cf. also p. 31 and 33).

39 Battegazzore 1979, pp. 55-56. For more on difficulties of translating and interpreting $\tau \rho \varepsilon ́ \varphi o v \tau \alpha \iota$ see mainly Mourelatos 1965, pp. 259-265. Cf. also Ostwald 1969, p. 27, n. 1. 
not be read elliptically in the sense of «feed on the divine one [law]» but could well be translated as «are fed by the one, which is divine» (cf. B 32) ${ }^{40} ; 2$ ) the primary message of the statement is not about identifying $\lambda$ ó ${ }^{\prime} \varsigma$ sith the law and asserting a superiority of divine law over human ones, but rather about identification of the common $\lambda$ ó $\gamma o \varsigma$ with one deity and its superiority over '

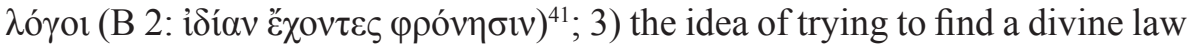
shared by the new laws of various communities would be unprecedented not only among the pre-Socratic philosophers, who focused mainly on a divine foundation of justice (equilibrium) ${ }^{42}$, but quite unique also within Heraclitean

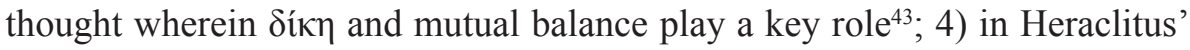
view, human laws could hardly provide a community with a commendable kind of underpinning since in his early life, they tended to focus on one particular problem, and tried to enforce the legalised solution in perpetuity, while towards the end of his life, Heraclitus may well have encountered situations where laws would be frequently and variously changed and altered to suit the current interest of representatives of different power groups, which sometimes resulted in laws contradicting each other ${ }^{44}$.

Surely, ever since Hesiod some Greek intellectuals discerned some regularity and order in the course of affairs dictated by the customs of their forefathers, and placed the origin of this order in the divine sphere (especially in the power of Zeus $)^{45}$. It is also beyond doubt that even in Classical times and later,

${ }^{40}$ Cf. Guthrie 1962, p. 425; Cleve 1965, p. 93: «are nourished by one, the divine»; Battegazzore 1979, pp. 56-57: «hanno vigore dall'uno divino»; and partly also Ostwald 1969, pp. 27-28, though he in the end tends to accept the traditional reading. A similar translation is advocated also by Mourelatos 1965, pp. 259 and 265 («are under wardship to one, the divine [law]»), García Calvo 1985, p. 40 («pues se crían todas las leyes humanas de la divina una y sola»), and Dilcher 1995, p. 50, but all these authors see a «law» underlying the «one».

${ }^{41}$ Cf. Reinhardt 1916, p. 215; Kirk 1978, p. 51; Mourelatos 1965, pp. 258, 266.

42 Burnet 1930, pp. 12-13; Vlastos 1947, p. 156 n.; Jones 1956, pp. 40-41; Long 2005, pp. $415-418$.

${ }_{43}$ Jones 1956, p. 40; Ostwald 1969, p. 28; Long 2005, pp. 417-418.

${ }^{44}$ Cf. also Jones 1956, pp. 55, 113-114; Ostwald 1969, pp. 39-40; Kirk 1978, p. 52; Quass 1971, pp. 14-21; Hölkeskampf 1999, p. 266 n.; Long 2005, p. 417. Extant evidence enables us to prove this only in the case of Athens - and partly also Crete - of the last third of the $5^{\text {th }}$ century but this process most likely started somewhat earlier and was not limited to Athens and Crete.

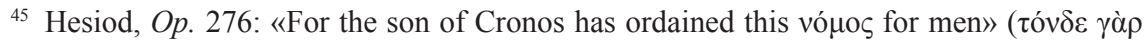

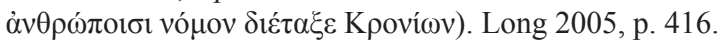


laws were justified in this way ${ }^{46}$. And while it is conceivable that Heraclitus could have been the first harbinger of such an approach, if he really wished to advise his contemporaries that they should fight for the divine order as if it were the city walls, he would have to be a little more explicit because no one is likely to look for this meaning in the extant words of B 44 .

The interpreter of the fragment, Diogenes, clearly understood vó os $_{\text {to }}$ mean human law. He put the statement about community's need to fight for laws in direct connection with a claim - quoted a little later - that «when [Ephesians] asked [Heraclitus] to give them laws, he refused because the community was already dominated by a bad constitution $\rangle^{47}$. This statement, too, is ahistoric ${ }^{48}$, though it seems that towards the end of the Archaic period Ephesians were busy issuing written laws left and right ${ }^{49}$. However, no Greek state had at that time a constitution in the sense of a clearly fixed set of principles, which all existing and prospective laws would have to conform to ${ }^{50}$. No such circumstance could have therefore prevented Heraclitus from coming up with some laws - which, according to legends, he $\mathrm{did}^{51}$. The idea of asking Hera-

${ }^{46}$ Plato, Protag. 322b6-d4 (transl. B. Jowett): «... but when they were gathered together, having no art of government, they evil treated one another, ... Zeus feared that the entire race would be exterminated, and so he sent Hermes to them, bearing reverence and justice ... Hermes asked Zeus how he should impart justice and reverence among men: Should he distribute them as the arts are distributed... "Shall this be the manner in which I am to distribute justice and reverence among men, or shall I give them to all?" "To all", said Zeus; "I should like them all to have a share; for cities cannot exist, if a few only share in the virtues, as in the arts.

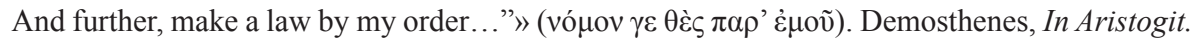

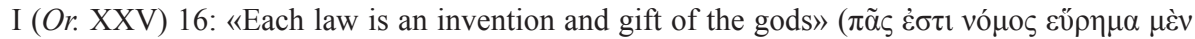

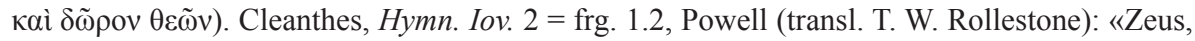

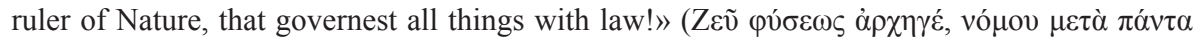

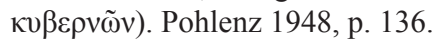

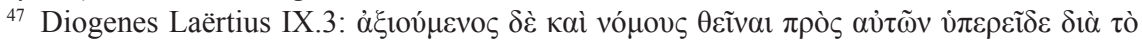

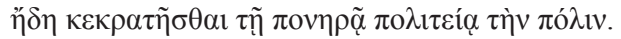

${ }_{48}$ Vlastos 1947, p. 166, n. 105; Kirk 1978, pp. 4-5.

${ }^{49}$ Hölkeskamp 1999, p. 114. Surviving stone blocks with inscriptions of laws probably originally belonged to the same wall even though the subjects of the decrees varied widely so that, e.g., rules for divination from the flight of birds (LSAM 30A) were immediately adjacent with rules of taking an oath in front of a judge (LSAM 30B).

${ }^{50}$ Hölkeskamp 1999, pp. 54-56, 263.

${ }^{51}$ Iamblichus, VP XXX 173 (transl. J. Dillon and J. Hershbell): «For unlike Heraclitus, who declared he would legislate for the Ephesians, and then decreed that the citizens should be

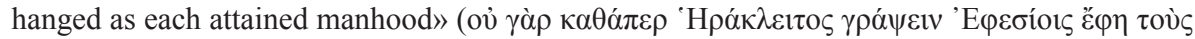

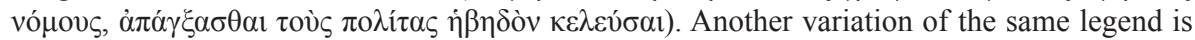


clitus to propose laws also does not sound likely. During the Archaic period, an exceptional individual could be in times of crisis asked to organise the political affairs of a state (this was the case of, e.g., Solon in Athens or Demonax in Mantineia). Emergency powers granted to this purpose were, however, limited to a particular problem, and despite later legends describing a far-reaching legislative aspect of these enterprises, had little to do with laws ${ }^{52}$.

The ahistoric nature of Diogenes' story would be of little interest to us if it weren't for the fact that fragment B 44 makes best sense in precisely this context. In Archaic times when law-making was a great novelty and by no means a commonplace achievement, people mainly aimed at creating and enforcing the best possible laws whose validity they then wished to secure in perpetuity ${ }^{53}$. In the Classical and Hellenistic period, however, when laws were often reformulated, abolished, misinterpreted or simply not adhered to, few believed that optimal laws on their own could ensure the wellbeing of a community. It was also necessary to find some way of ensuring that people would obey laws - and this became a prominent subject in the thinking of sophists and philosophers of the Classical period, and one of the main goals of Hellenistic pedagogy. However, it is questionable whether such interests can be ascribed already to Heraclitus.

\section{Analogy with trivial gnomic wisdom}

Fragment B 44 bears little resemblance with the dark, precisely formulated, and endlessly ambiguous maxims so characteristic of Heraclitus. It seems much closer to the so-called gnomic wisdom, which was in the Archaic period usually presented by poets, in Classical times by sophists, and during Hellenism by philosophers and pedagogues ${ }^{54}$. While maxims from the Archaic period vary in their quality - which was largely adjusted to the prospective audience - they are but seldom outright dumb, banal, or stolidly moralistic. Later on, however, such statements are far from rare because their main target group changed. While in Archaic times, $\gamma v \tilde{\omega} \mu \alpha \iota$ were intended mainly for

the advice the philosopher allegedly gave his citizens: following their wishes (DK $22 \mathrm{~A} 3 \mathrm{~b}$ in Plutarch's rendition), or not ( $D K 22 \mathrm{~A} 3 \mathrm{~b}$ in Themistius' rendition).

52 Just like in the case of Pythagoras or Hermodorus (see below). Cf. also Adcock 1927; Jones 1956, pp. 54-55; Hölkeskamp 1999, p. 114; Gagarin 2008, p. 44 and chap. III.

${ }_{53}$ Hölkeskamp 1999, p. 267.

${ }^{54}$ Cf. Bielohlawek 1940; Kindstrand 1981; Gärtner 1998. 
adult aristocrats who were the main agents and representatives of tradition, since the end of Classical times these sayings were increasingly created for children and adolescents who were instructed in simplified basics of ethics by the means of such straightforward, uncomplicated maxims. For example, when in the $5^{\text {th }}$ century Euryptolemus of Athens urged the assembly to observe laws and act in accordance with them, he did so for a particular reason, and in his speech he prepared the ground for his plea ${ }^{55}$. Statements about the need to guard and observe laws which are found in various gnomic collections dated after the last third of the $4^{\text {th }}$ century are no more than simple, unsubstantiated appeals, which students were simply supposed to memorise ${ }^{56}$.

The similarity of B 44 with trivial gnomic «wisdom» is, moreover, not limited to a resemblance in form: it concerns the content as well. Existence of sayings involving city walls is hinted on already by the lyrical poet Alcaeus, according to whom «men are a city's warlike wall» ${ }^{57}$. The decision of Phocaeans to leave their city rather than accept Persian rule, one the other hand, seems to have been dictated by a desire to defend the customs and laws of their forefathers rather than city wall ${ }^{58}$. An interesting, though not very close analogy is found in a statement that «best is democracy where all fear the law as they fear their master» because Plutarch ascribed this statement to Bias who share with Heraclitus the conviction that «most are bad» (see point 2$)^{59}$.

55 Xenophon, Hell. I 7.29: «Guard your laws thanks to which you became great, and do not

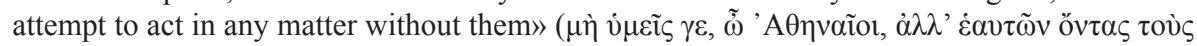

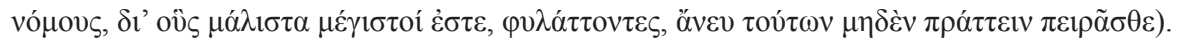

${ }^{56}$ DK 10.3, Chil. 19: «Obey the laws» (vó

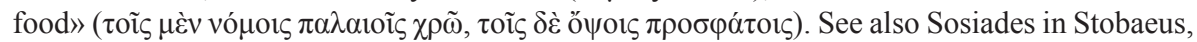
$E c l$. III 1.173, No. 2: «Obey the law» (vó $\mu \omega \pi \varepsilon \dot{\theta}$ ov). Similarly straightforward exhortations are also found among the Pythagorean $\dot{\alpha} \kappa o v ́ \sigma \mu \alpha \tau \alpha$, see Porphyry, VP 38: «Obey the laws» (vó $\delta \dot{\varepsilon} \pi \varepsilon i \theta \varepsilon \sigma \theta \alpha$ ) and $V P 42$ (transl. K. S. Guthrie): «Pluck not a crown, meant not to violate the

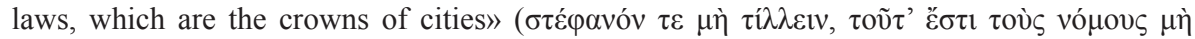

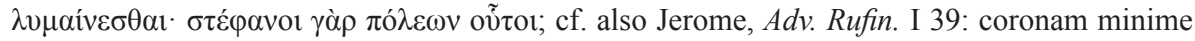
carpendam, id est leges urbium conservandas). Cf. Vollgraff 1917, p. 167.

${ }^{57}$ Frg. 112.10, Lobel \& Page $=35$, Diehl (this reading is based on the Schubart's generally

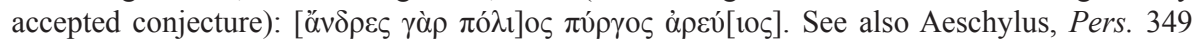
(transl. D. Theodoridis): «So long as their men live, the city’s towers will be secure» ( $\dot{\alpha} v \delta \rho \tilde{\omega} v$

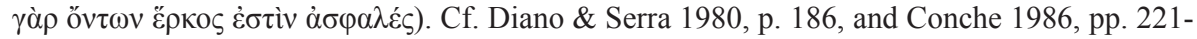
222 , who analyse the Ionian's relation to the walls of their communities and its proverbial status.

${ }^{58}$ Herodotus I 163-164.

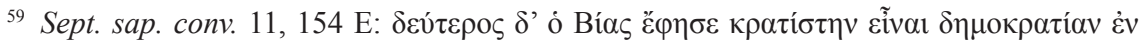

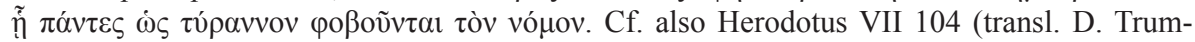


The metaphor of fighting for something important and a fighting for city walls appears also in several Roman and later authors, both of Greek and Latin origin, among whom Cicero stands out ${ }^{60}$. This author also called for a fight for laws (without any mention of city walls) ${ }^{61}$, and in one passage one even find a community, divine and human law, and city walls mentioned in close proximity, though not in the form of the metaphor known from Heraclitus ${ }^{62}$. An interesting parallel is found in the Septuagint: «... so they that forsake the law praise ungodliness; but they that love the law fortify themselves with a wall $\rangle^{63}$. The Hebrew original sounds a little differently ${ }^{64}$ but since the text is not very grammatically complex, the most likely reason for the difference seems to be the desire to use in translation a generally known proverb. That is what Clem-

bull and P. McNamara): «... for over them [Lacedemonians] is set Law as a master, whom

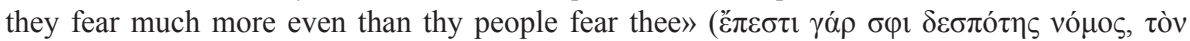
vं

${ }^{60} N D$ III 40.94 (transl. C. D. Yonge): «It concerns our altars, our hearths, out temples, nay, even the walls of our city, which you priests hold sacred; you who by religion defend Rome better than she is defended by her ramparts» (est enim mihi tecum pro aris et focis certamen et pro deorum templis atque delubris proque urbis muris, quos vos pontifices sanctos esse dicitis diligentiusque urbem religione quam ipsis moenibus cingitis); Acad. II 44.137 (transl. H. Rackham): «You, Lucullus, if you have accepted the views of your associate Antiochus, are bound to defend these doctrines as you would defend the walls» (haec tibi, Luculle, si es adsensus Antiocho familiari tuo, tam sunt defendenda quam moenia).

${ }^{61}$ Tusc. disp. IV 19.43 (transl. C. D. Yonge): «It becomes us to fight for our laws, our liberties, our country» (proelium rectum est hoc fieri, convenit dimicare pro legibus, pro libertate pro patria).

${ }^{62}$ Pro Sestio XLII 91 (transl. C. D. Yonge): «... then men surrounded with walls sets of houses joined together, which we now call cities, and divine and human laws began to be recognised» (tum domicilia coniuncta, quas urbis dicimus, invento et divino iure et humano moenibus saepserunt). Gigante 1957, p. 131, believes this passage to have been inspired by B 44 but in doing so, he strengthens the analogy by the insertion of $u t$ in front of moeniebus (as was suggested already by Rau 1842, p. 90), thus doing both something Cicero's text does not in any way require (Marcovich 1967, p. 535; most editors leave the text without any changes, yet various «improvements» have been suggested, cf., Maslowski 1986, p. 50), and reading the text with either quite extraordinary degree of empathy or, as may be, imagination, since that is exactly what is needed to see Heraclitus behind it.

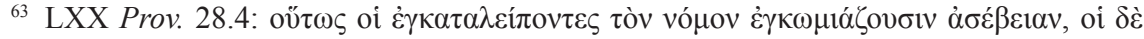

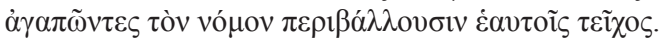

${ }^{64}$ An ecumenical translation of this passage is: «Those who abandon the law, praise a godless one, but those who obey the law, oppose them». 
ent of Alexandria and others most likely had in mind ${ }^{65}$. A similar saying is also reflected in various Biblical commentaries: John Chrysostom at various points speaks of laws being stronger than a city wall ${ }^{66}$, and according to Gregory of Nazianzus, the only real certainty is in the command to «not break the law, with which we fortified ourselves as if it were city walls $\rangle^{67}$.

All of the above-mentioned passages look more like various modifications of a well-known saying rather than reflections on B $44^{68}$, however close this fragment may stand to the original form of the proverb. Thinking in this direction is certainly legitimate, because there are a few proverbs that, with high probability, have been subsequently derived from Hereaclitus' sayings, without beeing able to retain their original depth ${ }^{69}$. On the other hand, there are

${ }^{65}$ Strom. II 19.101.2 (transl. Robert-Donaldson): «It is therefore plainly said, "Bad men do not understand the law; but they who love the law fortify themselves with a wall"» ( $\sigma \alpha \varphi \tilde{\omega} \varsigma$

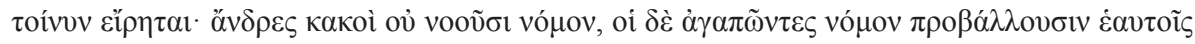
$\tau \varepsilon i \chi 0 \varsigma)$. Cf. also Origen, Exp. in Prov. XVII 164; Evagrius, Schol. in Prov. 343.

${ }_{66}$ John Chrysostom, in Isaiam V 2: «[The prophet] calls an enclosure a wall, law, or His Providence. For it is so that a law protects more certainly than a rampart. "I surrounded myself with a rampart" then means "I made a certainty firm". And since a rampart can often

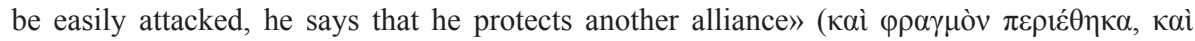

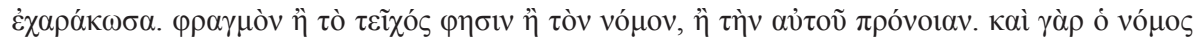

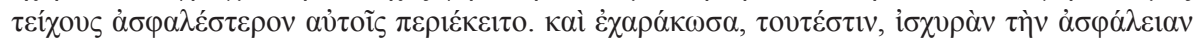

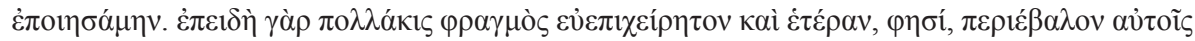
$\sigma v \mu \mu \alpha \chi i \alpha v)$. Fragm. in Jerem., PG LXIV.884, Migne: «That he why he forbade mixing with [other] nations, that is why he established laws mightier than city walls which do not approve of

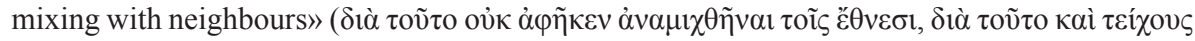

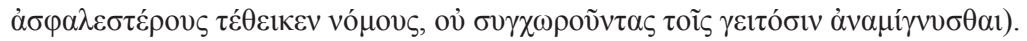

${ }^{67}$ In Mach. laud., PG XXXV.920, Migne: «There is one certainty and obedience of a command, that that is not to break the law, with which we fortified ourselves as if it were city walls»

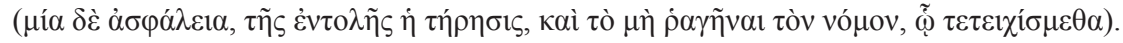

${ }^{68}$ See e.g. Marcovich 1967, p. 535, and Mondolfo \& Tarán \& Marcovich 2007, p. 746, that, however, explicitly mention only Cicero.

${ }^{69}$ Cf. Gregorius of Nazianz, Or. XXV 15, PG XXXV.1220, Migne: «To purify mud with

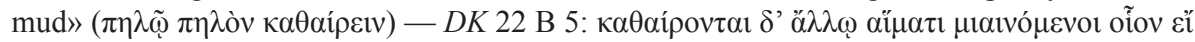

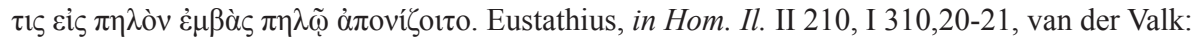

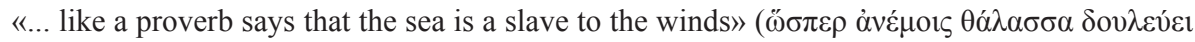

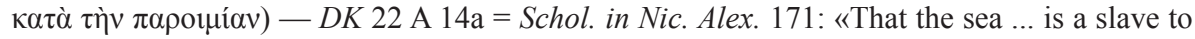

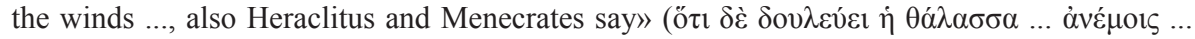

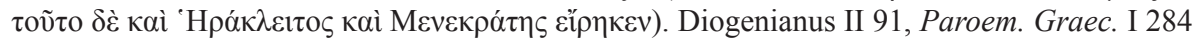

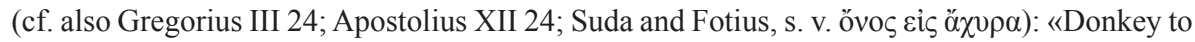

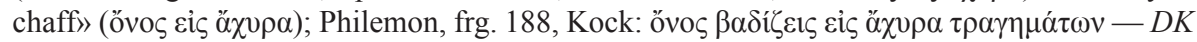


statements of Heraclitus which probably are an adaptation of old proverbs and sayings, but in comparison with them, they have much deeper meaning ${ }^{70}$.

Another possibility is that the moral statement about the necessity to fight for the law was attributed to Heraclitus by Scythinus of Teos (4. BCE), the iambic poet who allegedly «undertook to put the discourse of Heraclitus into verse» (transl. R. D. Hicks) ${ }^{71}$. Given that the B 44 carries traces of iambic meter, and that Scythinus produced verses similar to the «gnomic wisdom» of the Presocratics ${ }^{72}$, it is possible that he was also the author of B 44 . Whether he was inspired by a real statement of Heraclitus (B 114), by legend or by something completely different, is hard to decide. As the fr. B 44 does not seem to have undergone any philosophical or other changes, most likely none were actually carried out and Heraclitus' name was affixed to the saying ex post, in order to buttress its authority.

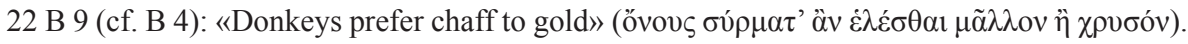
Strömberg 1954, pp. 41, 44; Marcovich 1967, p. 186.

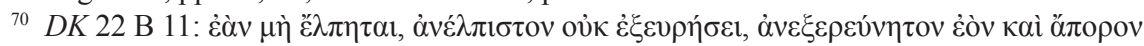

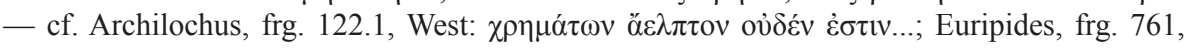

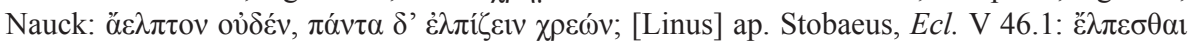

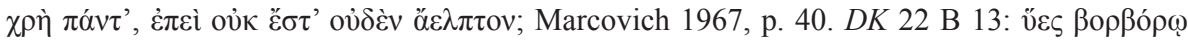

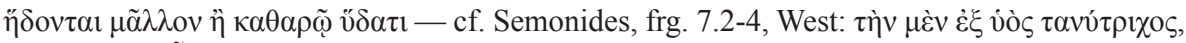

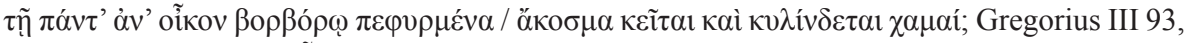

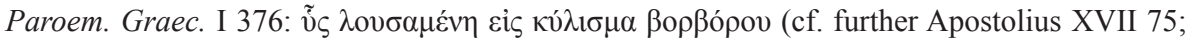
Athanasius, Epist. ad episc. Pers., PG XXVIII.1568, Migne; Didymus Caecus, in Zacchar. IV 9 etc.); Marcovich 1967, pp. 180, 182.

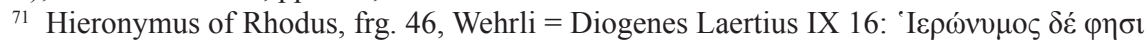

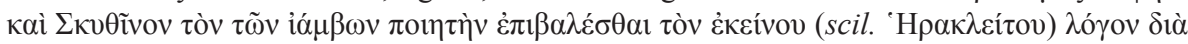

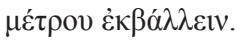

${ }^{72}$ Scythinus, frg. 2, West (transl. J. M. Edmonds): «Time's first and last of all things unto men, / hath all things in 't, is one and not-one ever, / is here when past 'tis, past when it is here, / inside itself it is and thence to itself / runs counter, and what seems to-day, in sooth / is yes-

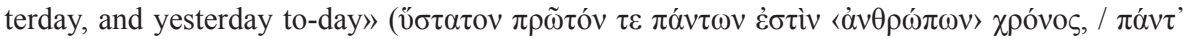

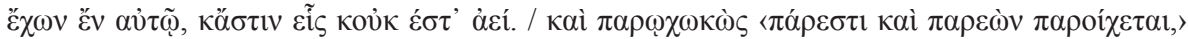

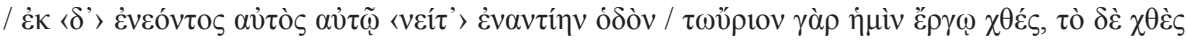
av́piov). Cf. Thales, $D K 11$ A 1 = Diogenes Laërtius I 35 (transl. R. D. Hicks): «The wisest is

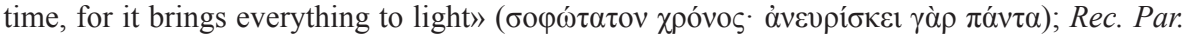
1, Pittacus 9 (= Tziatzi-Papagiani 1994, p. 214): «Time connects the greatest in the smallest

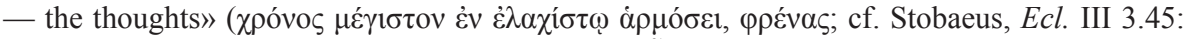

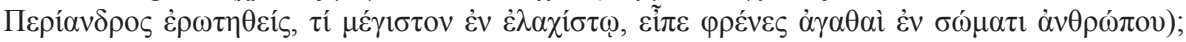
Euenus, frg. 9a, West (transl. J. M. Edmonds): «Time is the wisest and the foolishest of things»

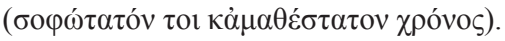




\section{Analogy with falsa in a moralistic spirit}

Fragment B 44 bears a marked resemblance to several statements, most of which are more or less generally seen as falsa. The great majority of these maxims have the form of rather simple, straightforward moralistic exhortations, which might fit perfectly well in a curriculum of an ancient or modern elementary school, but which look rather out of place among statements of a brilliant intellectual. Most of them are found only in late collections of gnomic statements of sundry provenance and mediocre quality.

B 127 (Aristocritus): «[Heraclitus] said to the Egyptians: "If they are gods, why do you grieve? If you grieve, you no longer think them gods"».

B 130 (Gnomol. Monac. Lat.): «It is inappropriate to joke in such a way that you become ridiculous».

B 131 (Gnomol. Par. Suppl.): «Opinion is an obstacle to progress».

B 132 (Gnomol. Vat.): «Honours conquer gods and men».

B 133 (Gnomol. Vat.): «Bad people are adversaries of truthful ones».

B 134 (Gnomol. Vat.): «To the educated, education is a second sun».

B 135 (Gnomol. Vat.): «The most direct way to fame is to become good».

B 137 (Stobaeus): «The course of things is fully determined by fate».

Trivial wisdoms of this kind were ascribed not only to Heraclitus but also to other pre-Socratics and various famous philosophers ${ }^{73}$. Fragment B 127, for example, is an anecdote, which circulated in various versions involving Xenophanes, Lycurgus, and an anonymous sage ${ }^{74}$. And yet, not all assertions of this kind are excluded from the corpus of authentic Heraclitean statements:

B 97 (Plutarch): «Dogs bark at every one they do not know».

B 95 (Plutarch): «It is best to hide one's folly, but it is hard when relaxed over the wine cups».

${ }^{73}$ See e.g. Empedocles, DK 31 A 20: Gnom. Par. 153 and 158 ascribes two rather stupid statements to Empedocles but Diogenes Laërtius assigns the former to Zeno of Elea (IX 29) and the latter to Xenophanes (IX 20).

${ }^{74}$ Xenophanes: Aristotle, Rhet. II 23, 1400b5; Plutarch, De Is. et Os. 70,379 B, De superst. 13, 171 E and Amat. 18, 763 C-D. Lycurgus: [Plutarch], Apopth. Lacon. 26, 228 E. Anonymous: Clement, Protr. II 24.3; Minucius Felix, Oct. XXII 2; Firmicus Maternus, Err. prof. rel. VIII 4. Great majority of scholars therefore rejects the authenticity of B 127 (Schleiermacher, Lassalle, Mullach, Bywater, Diels 1901, p. 29, D-K 1934/1992, p. 130, Marcovich 1967, p. 593, Walzer, Bollack \& Wismann 1972, p. 348, Kahn, Conche 1986, pp. 180-183, Colli, Robinson, Pradeau and others). 
B 99 (Plutarch): «If there were no sun, it would be night».

B 47 (Diogenes Laërtius): «Let us not conjecture at random about the greatest things».

B 43 (Diogenes Laërtius): «Wantonness needs putting out, even more than a house in fire».

B 97 is an old saying with no deeper meaning ${ }^{75}$, and yet its authenticity is seldom doubted ${ }^{76}$. B 95 and B 99 also seem to be imbued with general wisdoms of doubtful brilliance but even in these cases, objections against their genuineness are nowhere to be found ${ }^{77}$. All in all, it seems that in illo puncto scholars are not very consistent or else they take it for granted that Heraclitus for some unknown reason occasionally used popular proverbs and transformed their meaning ${ }^{78}$. Some experts find fragment B 47 rather hard to swallow ${ }^{79}$ but then again no one objects to B 43, even though it is about as profound and to the point as B 47 and several generally rejected falsa ${ }^{80}$ (but it contains the popular motif of fire, often seen as characteristically Heraclitean).

\section{Connection with $\mathrm{B} 43$}

Nonetheless, problems with B 43 have even deeper roots. Its only source is as in the case of B 44 - the biographer and doxographer Diogenes Laërtius,

${ }^{75}$ Marcovich 1967, p. 86: «This is a popular adage. Its implication is obscure».

${ }^{76}$ See perhaps only Kirk 1978, p. 158.

${ }_{77}$ B 95: experts disagree only on which parts of Plutarch's sentence can be accepted as an authentic statement (for more on this, see Mouraviev 2006, III 3.B/i, pp. 241-242); B 99: scholars usually try to get at a hidden «Heraclitean» meaning by combining both textual variants. Obviousness and banality of the statement is accepted by only a handful of experts (Gigon 1935, pp. 78-79: «Der Satz ist recht banal»; Guthrie 1962, p. 484; Marcovich 1963, pp. 326327).

${ }^{78}$ Gigon 1935, p. 26 («Heraklit oft populäre Gedanken aufnimmt [cf. frg. 43, 96, 119]») and 70 («Heraklit lehnt sich gerne an volkstümliche Vorstellungen an [cf. frg. 43, 119]»); Kirk \& Raven 1957, p. 214: «251 (i.e. B 43) ... shows how conventional the practical side of Heraclitus's ethics often was. ... The insistence on respect for law in 252 (i.e. B 44) ... [is] again expressed in conventional terms». Zeller \& Nestle 1920, p. 914, believe B 44 to be a version of the popular maxim dulce est pro patria mori, thus also rejecting the interpretation of Schuster 1873 , p. 303, according to whom B 44 was meant ironically.

79 Authenticity of B 47 is doubted, e.g., by Schleiermacher, Mullach, Gigon 1935, p. 97, Marcovich 1967, p. 572, Robinson 1987, p. 111, and Vítek 2003, p. 367.

${ }^{80}$ Kirk 1949, p. 393: «We know of course that in the sphere of practical ethics his remarks were occasionally indistinguishable from those of other sages of his time, e. g., fr. 43D». 
who in the introductory part of Heraclitus' biography quotes six fragments (B 40-B 44 and B 121). Four of these are in various ways confirmed by other sources but B 43 and B 44 are not found anywhere else. Moreover, these two statements are closely related: they are inserted into the same indirect sen-

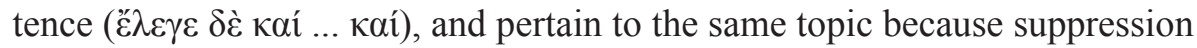
(«putting out») of arrogance (B 43: «Wantonness needs putting out, even more than a house in fire») opposed to a fight for and adherence to laws (B 44) creates a type of contrast characteristic of authors of the Archaic period who often put arrogance and lawlessness (v̋ $\beta \rho \iota, \delta v \sigma v o \mu i ́ \alpha)$ in opposition with order and

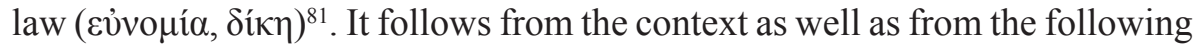
fragment B 121, where Heraclitus castigates his fellow citizens for banishing Hermodorus, «the most valuable man among them», that both B 43 and B 44 pertain to the same subject: they both address the people of Ephesus and the bad political system they established.

One could therefore suppose that the indirect sentence fronting B 121 is not combining two independent and cleverly chosen quotations from Heraclitus but rather two maxims of vague origin which were supposed to illustrate Heraclitus' censorious disposition and his immediate concern with political affairs of his native city ${ }^{82}$. The sentence makes best sense as an introduction to B 121 because Diogenes — and many later authors - saw Hermodorus as a law-giver ${ }^{83}$. This interpretation is further supported by Diogenes's words after the quotation of B 121, where he puts even Heraclitus in such a lawmaking position (see point 4).

The phrase «to put out arrogance» (or «wantonness») was relatively common $^{84}$, and that is why it is possible it was later imputed to Heraclitus based

${ }^{81}$ Cf. for example $O d$. XVII 485-487; Solon, frg. 4.15-21, 32-39, Edmonds; Theognis 289292 et al. Ostwald 1969, pp. 64-66.

${ }^{82}$ Deichgräber 1939, pp. 12-13; Schwartz 1905, p. 748; Kirk 1978, p. 4; Rosén 1988, p. 37 («Heraclitus may be considered the author of the simile..., but not of the wording»).

${ }^{83}$ Cicero, Tusc. disp. V 36.105. Deichgräger 1939, p. 13; Münzer, s. v. Hermodorus (3), in: RE VIII/15, 1912, pp. 859-861; Marcovich 1967, p. 541, n. 1; Kirk 1978, pp. 1-2; Hölkeskamp 1999, pp. 112-114.

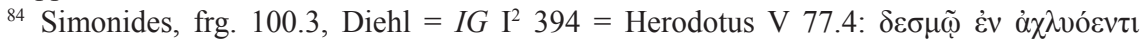

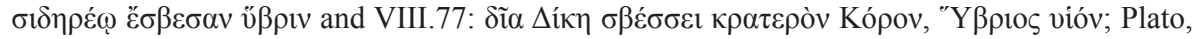

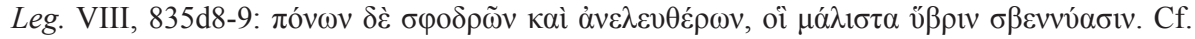
also Euripides, Or. 696-697 (transl. I. Johnson): «For when people fall into frenzy / it's like

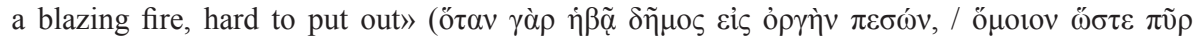
$\kappa \alpha \tau \alpha \sigma \beta \varepsilon \dot{\sigma} \sigma \alpha \imath \lambda \alpha ́ \beta \rho o v)$. Marcovich 1967, p. 532. 
on the association with fire and putting that out, that is, notions that do have a place in his work (B 30, B 76 with the comments of authors). On the other hand, the construction of the fragment does look very Heraclitean, and one can read into it various meanings. Question remains, though, whether scholars would try so hard to do had they seriously doubted Heraclitus' authorship. This much is certain: as long as B 43 is not in doubt, it indirectly supports the authenticity of B 44. Et vice versa: if someone concludes that there is a problem with B 44, then B 43 will also have to be more closely investigated ${ }^{85}$.

\section{Conclusion}

Do the above-mentioned problems and suspicions require an unconditional rejection of fragment B 44 from the corpus of authentic Heraclitean statements? Not quite. The aforementioned objections can be, at least to some degree, countered. I shall now only briefly outline the ways in which this could be done.

The language of the Ephesian philosopher is uncommonly idiosyncratic, many-layered, and hard to penetrate, all of which makes it difficult to tell apart the typical from the anomalous (see section 1). Inclusion of one statement or its part into another occurs in other fragment pairs without necessarily casting doubt on their authenticity (see section 2). Heraclitean views and theories which span over several fragments can be clearly summarised only with utmost difficulty. It is therefore very tricky to claim that some Heraclitean statement contradicts another - especially as this author was so fond of creating real and apparent contradictions (see section 3). Some author may have replaced the original word for «law» by its later equivalent and it is also possible to read vó $\mu$ o $\zeta$ in the fragment according to its contemporary meaning. One may even consider shifting the timing of Heraclitus' life deeper into the $5^{\text {th }}$ century (see section 4). Similarity between doubtful Heraclitean statements and gnomic banalities could have arisen from being taken out of context or from an inaccurate reproduction of the original meaning. It could even be a consequence of intentional and systematic shifts in meaning, which the philosopher engaged in (see section 5). After all, censorious mood and moralistic overtones are found even in some Heraclitean statements whose authenticity

${ }^{85}$ Cf. already Deichgräber 1939, p. 13: «Die Gnomen [i.e. B 43 and B 44], die als solche im Gegensatz zu den kritischen Zitaten stehen, gehören inhaltlich doch auch wieder in den Zusammenhang hinein: die Erklärung muss beides beachten». 
is beyond any doubt. One can thus imagine that Heraclitus for some reason occasionally resorted to simpler appellative exclamations and general moralisms (see section 6). The insertion of two Heraclitean fragments into one's indirect sentence has its counterparts also in cases of genuine statements (B 46, B 80), which is why a connection between B 44 and the unproblematic fragment B 43 rather supports than weakens its authenticity (see section 7).

Yet, though the authenticity of B 44 may be supportable, anyone who wishes to uphold it should deal with the seven above-mentioned kinds of objections and offer well-grounded answers. Until such time, it seems warranted and reasonable to treat this fragment at least dubious. It is also clear that even after dealing with most of the controversial points, B 44 cannot be considered in all respects a fully trustworthy testimony. For example, even though the atypically placed articles may be explained as infelicitous insertions by other authors, B 44 can hardly be used as fully valid evidence in an analysis of how Heraclitus treated this phenomenon. And it would be similarly misleading to include B 44 in an investigation of the use of vó $\mu$ os in the sense of «law» because at the end of the Archaic period, the word did not yet acquire this meaning.

\section{BIBLIOGRAPHY}

Adcock, F. E. 1927: «Literary Tradition and Early Greek Code-Makers», Cambridge Historical Journal 2/2, pp. 95-109.

Battegazzore, A. M. 1979: Gestualità e oracolarità in Eraclito, Milano.

Bernays, I. 1848: Heraclitea. Particula I, Bonn.

Bielohlawek, K. 1940: Hypotheke und Gnome, Leipzig.

Bollack, J. 1970: «The Review of M. Marcovich, Heraclitus», Gnomon 42, pp. 1-10.

Bollack, J. and Wismann, H. 1972: Héraclite ou séparation, Paris.

Burnet, J. 1930: Early Greek Philosophy, London.

Bywater, I. 1880: «Heraclitus and Albertus Magnus», Journal of Philology 9/18, pp. 230-234.

Cleve, F. 1965: The Giants of Pre-Sophistic Greek Philosophy I-II, The Hague.

Colli, G. 1980: La sapienza greca III: Eraclito, Milano.

Conche, M. 1986: Héraclite, Fragments, Paris.

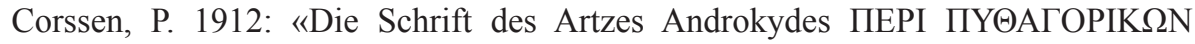
$\Sigma \mathrm{YMBO} \Lambda \Omega \mathrm{N} », R h M 67$, pp. 240-263.

Deichgräber, K. 1939: «Bemerkungen zu Diogenes’ Bericht über Heraklit», Philologus 93, pp. 12-30.

Diano, C. and Serra, G. 1980: Eraclito. I frammenti e le testimonianze, Milano. 
Diels, H. 1901: Herakleitos von Ephesos, Berlin.

Diels, H. 1903: Die Fragmente der Vorsokratiker, Berlin $\left(1906^{2} ; 1912^{3} ; 1922^{4}\right)$.

Diels, H. and Kranz, W. 1934 [1992 ${ }^{18}$ ]: Die Fragmente der Vorsokratiker I, Berlin.

Dilcher, R. 1995: Studies in Heraclitus, Hildesheim.

Dilcher, R. 2005: «Im-Fluss-sein (Heraklit, B 12)», in Rechenauer, G. (ed.), Frühgriechisches Denken, Göttingen, pp. 203-216.

Fränkel, H. 1938: «A Thought Pattern in Heraclitus», AJPh 59/3, pp. 309-337.

Freeman, K. 1946: The Pre-Socratic Philosophers, Oxford.

Gagarin, M. 2005: «The Unity of Greek Law», in Gagarin, M. and Cohen, D. (eds.), Ancient Greek Law. The Cambridge Companion to Ancient Greek Law, Cambridge-New York, pp. 29-40.

Gagarin, M. 2008: Writing Greek Law, Cambridge.

García Calvo, A. 1985: Razón común. Edición crítica, ordenación, traducción y comentario de los restos del libro de Heraclito, Madrid.

Gärtner, H. A. 1998: s. v. «Gnome», in Der Neue Pauly IV, Stuttgart, pp. 1108-1116.

Gigante, M. 1957: «Ad Cic. Pro P. Sestio 42,91», PP 12, p. 131.

Gigon, O. 1935: Untersuchungen zu Heraklit, Leipzig.

Gomperz, Th. 1886: «Zu Heraklits Lehre und den Überresten seines Werkes», Sitzungsberichte Wiener Akademie 113, pp. 997-1055.

Guthrie, W. K. C. 1962: A History of Greek Philosophy I, Cambridge, pp. 403-492.

Heinimann, F. 1945: Nomos und Physis, Basel.

Hölkeskamp, K.-J. 1999: Schiedsrichter, Gesetzgeber und Gesetzgebung im archaischen Griechenland, Stuttgart.

Jones, W. J. 1956: The Law and Legal Theory of the Greeks: An Introduction, Oxford.

Kahn, Ch. H. 1981: The Art and Thought of Heraclitus, Cambridge.

Kindstrand, J. F. 1981: Anacharsis. The Legend and the Apopthegmata, Stockholm.

Kindstrand, J. F. 1984: «The Cynics and Heraclitus», Eranos 82, pp. 149-178.

Kirk, G. S. 1949: «Heraclitus and Death in Battle (Fr. 24D)», AJPh 70, pp. 384-393.

Kirk, G. S. 1978 [1954'; 1962: rev. ed.]: Heraclitus, the Cosmic Fragments, Cambridge.

Kirk, G. S., Raven, J. E. 1957: The Presocratic Philosophers, Cambridge.

Kranz, W. 1934: «Vorsokratisches I», Hermes 69, pp. 114-119.

Lassalle, F. 1858: Die Philosophie Herakleitos des Dunklen von Ephesos I-II, Berlin.

Latte, K. 1946: «Der Rechtsgedanke im archaischen Griechentum», $A \& A$ 2, pp. 6376.

Lledó, E. 1994: «La lucha for la ley (Heráclito, fragmento B 44)», in Lledó, E., Memoria de la ética, Madrid, pp. 254-268.

Long, A. A. 2005: «Law and Nature in Greek Thought», in Gagarin, M., Cohen, D. (eds.), The Cambridge Companion to Ancient Greek Law, Cambridge, pp. 412430 . 
Marcovich, M. 1967 [Sankt Augustin 2001²]: Heraclitus, Mérida.

Marcovich, M. 2008 [2001ํㅣ: Diogenis Laertii Vitae philosophorum I, Berolini.

Mondolfo, R., Tarán, L. and Marcovich, M., 2007: Eraclito. Testimonianze, imitazioni e frammenti. Introduzione di G. Reale, Milano.

Maslowski, T. 1986: Oratio pro Sestio, Stuttgart.

Mouraviev, S. 2000: Heraclitea II A.2: Traditio (A), Sankt Augustin.

Mouraviev, S. 2002: Heraclitea III 3.A: Recensio. Fragmenta, Sankt Augustin.

Mouraviev, S. 2003: Heraclitea III 1: Recensio. Memoria, Sankt Augustin.

Mouraviev, S. 2006: Heraclitea III 3.B/i-iii: Recensio. Fragmenta, Sankt Augustin.

Mourelatos, A. P. D. 1965: «Heraclitus, Fr. 114», AJPh 86, pp. 258-266.

Mullach, F. G. A. 1860: Fragmenta philosophorum Graecorum I, Paris, pp. 310-329.

Münzer, F. 1912: s. v. Hermodorus (3), in RE VIII/15, pp. 859-861.

Ostwald, M. 1969: Nomos and the Beginnings of the Athenian Democracy, Oxford.

Patrick, G. T. W. 1889: The Fragments of the Work of Heraclitus of Ephesos On Nature, Baltimore .

Pohlenz, M. 1948: «Nomos», Philologus 97, pp. 135-142.

Pradeau, J.-F. 2002: Héraclite, Fragments. Citations et témoignages, Paris.

Quass, F. 1971: Nomos und Psephisma. Untersuchung zum griechischen Staatsrecht, München.

Rau, S. I. E. 1842: Variarum lectionum lib. ad Ciceronis orationes pertinens II, Lyon.

Reinhardt, K. 1916: Parmenides und die Geschichte der griechischen Philosophie, Bonn.

Robinson, T. M. 1987: Heraclitus: Fragments, University of Toronto Press.

Rosén, H. B. 1988: «Early Greek Grammar and Thought in Heraclitus», Proceedings of the Israel Academy of Sciences and Humanities 7/2, pp. 1-42.

Schleiermacher, F. 1838: Herakleitos der Dunkle von Ephesos, in Schleirmacher, F., Sämtliche Werke III 2, Berlin, pp. 26-27.

Schuster, P. 1873: «Heraklit von Ephesus. Ein Versuch dessen Fragmenten in ihrer ursprünglichen Ordnung wiederherzustellen», Acta Societatis philologae Lipsiensis 3, pp. 1-397.

Schwartz, E. 1905: s. v. «Diogenes (40) Laertius», RE V/9, pp. 738-763.

Snell, B. 1926: «Die Sprache Heraklits», Hermes 61, pp. 353-381.

Ströberg, R. 1954: Greek Proverbs. A Collection of Proverbs and Proverbial Phrases which are not Listed by the Ancient and Byzantine Paroemiographers, Göteborg.

Thomas, R. 2005: «Writing, Law, and Written Law», in Gagarin, M., Cohen, D. (eds.), Ancient Greek Law. The Cambridge Companion to Ancient Greek Law, Cambridge-New York, pp. 41-60.

Tziatzi-Papagiani, M. 1994: Die Sprüche der sieben Weisen: Zwei byzantinische Sammlungen, Stuttgart-Leipzig.

Vítek, T. 2003: «Heraclitus, fr. B 11, D-K», PP 58/332, pp. 356-371. 
Vlastos, G. 1947: «Equality and Justice in Early Greek Cosmologies», CPh 42, pp. 156-179.

Vollgraff, W. 1916: «De duobus Heracliti fragmentis», Mnemosyne 44, pp. 423-427.

Vollgraff, W. 1917: «De duobus Heracliti fragmentis», Mnemosyne 45, pp. 166-180.

Walzer, R. 1939: Eraclito. Raccolta dei frammenti e traduzione italiana, Firenze.

Wheelwright, Ph. 1959: Heraclitus, Princeton.

Wellmann, E. 1912: s. v. «Heraclitus (10)», in RE XV, pp. 504-508.

Zeller, E. 1889: «Über die ältesten Zeugnisse zur Geschichte des Pythagoras», Sitzungsberichte der Bayerischen Akademie der Wissenschaften zu Berlin, pp. 985996.

Zeller, E. and Nestle, W. 1920: Die Philosophie der Griechen I 2, Leipzig. 